\title{
KERAGAMAN MAKANAN DAN HUBUNGANNYA DENGAN STATUS GIZI BALITA: ANALISIS SURVEI KONSUMSI MAKANAN INDIVIDU (SKMI)
}

\author{
Dietary Diversity and It's Association with Nutritional Status Among Under Fives: Results of Indonesian \\ Food Consumption Survey (IFCS)
}

\author{
Nur Handayani Utami, Rofingatul Mubasyiroh \\ Pusat Penelitian dan Pengembangan Upaya Kesehatan Masyarakat, Badan Penelitian dan \\ Pengembangan Kesehatan, Kementerian Kesehatan RI \\ E-mail: nur_handayani80@yahoo.com
}

\begin{abstract}
Food consumption is one of the vital things that can determine the nutritional status of children. One indicator of the dietary quality of children is dietary diversity. This analysis was carried out to analyze dietary diversity and its relationship to the nutritional status of under-five children in Indonesia. The analysis was carried out on the data of the Individual Food Consumption Survey (IFCS). A total of 5,395 children were sampled in this analysis. Food consumption was collected through $24 \mathrm{hr}$ recall. The dependent variable in this analysis is the nutritional status of children (weight for age). The main independent variable is dietary diversity. The results of the analysis show that the types of food consumed most by children under five in Indonesia are cereals, roots, and tubers while the types of food groups that are the least consumed are fruits and nuts. The results of the analysis also show that the higher the age, mother's education and the economic level, the more diverse the consumption of food. The diversity of consumption is also higher for children in urban areas. The results of the analysis show that the diversity of food consumed by infants is related to nutritional status. Less diverse consumption mainly increases the risk of children experiencing severe underweight, even though this relationship is weak. Conversely, less diverse consumption reduces the risk of overweight.
\end{abstract}

Keywords: dietary diversity, nutritional status, under-five children

\section{ABSTRAK}

Konsumsi makanan merupakan salah satu hal vital yang dapat menentukan status gizi anak. Salah satu indikator kualitas konsumsi anak adalah keragaman makanan. Analisis ini dilakukan untuk menganalisis keragaman makanan serta hubungannya dengan status gizi balita di Indonesia. Analisis dilakukan terhadap data Survei Konsumsi Makanan Individu (SKMI). Sebanyak 5.395 balita menjadi sampel dalam analisis ini. Pengumpulan data konsumsi makanan diperoleh dengan metode $24 \mathrm{hr}$ food recall. Variabel dependen dalam analisis ini adalah Status Gizi balita (BB menurut Umur). Variabel independen utama yaitu keragaman makan balita. Hasil analisis menunjukkan bahwa jenis bahan makanan yang paling banyak dikonsumsi oleh anak balita di Indonesia adalah serealia, akar, dan umbi-umbian sementara jenis kelompok bahan makanan yang paling sedikit dikonsumsi yaitu buah-buahan serta kacang-kacangan. Hasil analisis juga menunjukkan bahwa semakin tinggi usia, pendidikan ibu serta tingkat ekonomi maka semakin beragam konsumsi makanannya. Keragaman konsumsi juga lebih banyak pada balita di perkotaan. Hasil analisis menunjukkan bahwa keragaman bahan pangan yang dikonsumsi balita berhubungan dengan kondisi status gizi. Konsumsi yang kurang beragam terutama meningkatkan risiko seorang balita mengalami berat badan sangat kurang, meskipun hubungan ini lemah. Sebaliknya, konsumsi yang kurang beragam menurunkan resiko terjadinya berat badan lebih.

Kata kunci: keragaman makanan, status gizi, balita

Doi:10.36457/gizindo.v\%vi\%i.467

www.persagi.org/ejournal/index.php/Gizi_Indon 


\section{PENDAHULUAN}

K eragaman makanan merupakan kunci dari konsumsi makanan yang berkualitas. Kementerian kesehatan $\mathrm{RI}$ melalui Pedoman Gizi Seimbang menyebutkan bahwa dalam rangka mengatasi beban gizi ganda, masyarakat perlu mengonsumsi makanan dengan prinsip gizi seimbang. Prinsip gizi seimbang yaitu dalam konsumsi makanan sehari-hari harus mengandung zat gizi dalam jumlah dan jenis yang sesuai dengan kebutuhan setiap orang atau kelompok umur. Prinsip Gizi Seimbang memiliki 4 pilar, yang salah satu nya adalah keanekaragaman pangan. Keanekaragaman pangan diartikan sebagai anekaragam kelompok pangan yang terdiri dari makanan pokok, lauk pauk, sayuran dan buahbuahan serta air. ${ }^{1}$

Keanekaragaman makanan (Dietary Diversity), didefinisikan sebagai jumlah dari kelompok makanan yang dikonsumsi selama periode 24 jam, telah didokumentasikan sebagai indikator yang valid dan dapat diandalkan kecukupan makanan dari anakanak. Oleh karena itu, keanekaragaman makanan adalah variabel proksi yang cukup mudah untuk mengukur asupan gizi anak. Organisasi Kesehatan Dunia (WHO) menggunakan Keragaman Makanan sebagai salah satu indikator kunci untuk menilai praktek anak makan. ${ }^{2}$

Permasalahan gizi balita masih terjadi di Indonesia. Hasil Riset Kesehatan Dasar (Riskesdas) menyatakan bahwa masalah kekurangan gizi yang utama terjadi yaitu stunting pada anak. Riskesdas memberikan gambaran yang fluktuatif akan status berat badan kurang pada balita $(B B / U<-2 S D)$, yaitu dari 18,4 persen (2007) menurun menjadi 17,9 persen (2010) kemudian meningkat lagi menjadi 19,6 persen (tahun 2013). ${ }^{3}$ Di sisi lain, anak yang mengalami kegemukan juga mengalami peningkatan proporsi nya. Gizi lebih teridentifikasi sebesar 11,9 persen pada tahun 2013. ${ }^{3}$

Studi dan analisis yang pernah dilakukan sebelumnya telah menemukan bahwa terdapat hubungan antara keragaman makanan dengan status gizi anak. Analisis keragaman makanan belum banyak dilakukan pada data hasil survei nasional di Indonesia. Survei Konsumsi Makanan Indonesia merupakan survei konsumsi makanan individu yang dilaksanakan di seluruh provinsi di Indonesia. Sehingga analisis ini dilakukan untuk menganalisis keragaman makanan serta hubungannya dengan status gizi balita di Indonesia.

\section{METODE PENELITIAN}

Survei Konsumsi Makanan Individu (SKMI) merupakan survei konsumsi makanan individu nasional pertama yang pernah dilaksanakan di Indonesia pada tahun 2014. Populasi SKMI adalah semua rumah tangga (RT) di Indonesia. Sampel SKMI sebanyak 2080 blok sensus (BS) yang dipilih secara acak dari 3.000 BS sampel Riskesdas 2013 keterwakilan provinsi. Jumlah RT SKMI adalah 51.127 dan jumlah individu adalah 191.524 individu. Sampel dalam analisis ini adalah seluruh anak balita usia 6-59 bulan yang merupakan sampel dari Survei Konsumsi Makanan Individu dan memiliki data yang lengkap. Seluruh sampel balita ikut dalam analisis yaitu sebanyak 5.395 balita. $^{4}$

Pengumpulan data konsumsi makanan diperoleh dengan metode $24 \mathrm{hr}$ food recall. Dalam recall konsumsi makanan dikumpulkan jenis makanan/minuman yang dikonsumsi serta berat per jenis bahan makanan/minuman tersebut. Pelatihan untuk enumerator mengenai metode pengumpulan data konsumsi individu telah dilaksanakan sebelumnya. Seluruh enumerator memiliki latar belakang pendidikan gizi atau kesehatan. Pada saat pengumpulan data, para enumerator dilengkapi dengan buku foto makanan yang digunakan untuk membantu responden memperkirakan jenis dan jumlah makanan/minuman yang dikonsumsi. Supervisi juga dilakukan oleh peneliti dari NIHRD untuk memastikan bahwa pelaksanaan pengumpulan data dilakukan dengan benar. ${ }^{4}$

Selain itu juga dilakukan pengukuran berat badan. Pengukuran berat badan dilakukan pada seluruh responden yang terpilih menjadi sampel SKMI. Pengukuran berat badan dilakukan dengan menggunakan timbangan berat badan digital dengan ketelitian $0,1 \mathrm{Kg}$ dengan merk AND.

Variabel dependen dalam analisis ini adalah Status Gizi balita (BB menurut Umur) yang dihitung menggunakan WHO Antro 2006 dan dikelompokkan menjadi berat badan lebih (BB/U > $2 \mathrm{SD})$, normal $(\mathrm{BB} / \mathrm{U}-2 \leq \mathrm{SD}>2)$, berat badan kurang $(\mathrm{BB} / \mathrm{U}-2<\mathrm{SD} \leq-3)$ dan 
berat badan sangat kurang(BB/U $<-3 \mathrm{SD}) .^{5}$ Variabel independen utama yaitu keragaman makan balita. Keragaman bahan makan anak merupakan kategori keragaman bahan makan anak terhadap 8 kelompok bahan makanan; 1) serealia, akar dan umbi-umbian, 2) kacangkacangan, 3) buah, 4) sayuran, 5) daging dan ikan, 6) telur, 7) susu dan olahannya serta lemak pada 24 jam sebelumnya. Keragaman makanan dikategorikan cukup jika anak mengonsumsi $\geq 4$ macam kelompok bahan makanan. $6,7,8$

Variabel independen lainnya sebagai covariat yaitu jenis kelamin; usia anak: 6-8 bulan, 9-12 bulan, 13-23 bulan, 24-59 bulan; usia ibu: $<20$ dan $>35$ tahun, 20-35 tahun; pendidikan ibu: tidak sekolah, pendidikan rendah (lulus SD-SMP), pendidikan menengah (lulus SMA), dan tinggi (Iulus diploma/perguruan tinggi); dan pekerjaan: tidak bekerja dan bekerja/sekolah; sosial ekonomi rumah tangga: berdasarkan kelompok kuintil pengeluaran rumah tangga; dan kategori tempat tinggal: perkotaan dan perdesaan.

Analisis data dilakukan secara deskriptif dan multivariat. Analisis deskriptif untuk mengetahui karakteristik anak balita (jenis kelamin, usia, keragaman konsumsi dan status gizi), karakteristik ibu (umur, tingkat pendidikan, pekerjaan) dan rumah tangga balita (sosial ekonomi rumah tangga dan wilayah tempat tinggal). Distribusi status gizi balita serta hubungannya menurut karakteristik dilakukan dengan bivariat. Distribusi keragaman konsumsi balita menurut karakteristik dilakukan dengan bivariat. Hubungan antara keragaman makanan balita dengan status gizi balita dianalisis dengan menggunakan analisis multivariate logistik multinomial. Analisis data dilakukan dengan menggunakan software STATA.

\section{HASIL}

Sejumlah 5.395 anak balita dianalisis dalam penelitian ini. Jumlah balita sebanding antara laki-laki dan perempuan, dengan proporsi terbesar pada kelompok umur dua tahun ke atas. Tabel 1 menunjukkan seperlima balita mengalami gangguan berat badan kurang-buruk, dan sebagian besar konsumsi makanan yang beragam.

Tabel 2 menunjukkan kondisi status gizi balita berbeda bermakna berdasarkan umur ballita, umur ibu, pendidikan ibu, kondisi sosial ekonomi dan tempat tinggal. Semakin tinggi usia, maka semakin besar proporsi anak mengalami berat badan kurang. Berat badan sangat kurang paling banyak diderita anak usia 9-11 bulan. Anak yang mengalami berat badan kurang lebih banyak terjadi pada ibu yang berusia $<20$ dan $>35$ tahun. Sedangkan berat badan sangat kurang banyak dialami anak dengan ibu berusia 20-35 tahun. Semakin rendah pendidikan ibu, maka semakin besar proporsi anak mengalami berat badan kurang dan buruk. Begitu juga pola untuk status ekonomi, semakin rendah status ekonomi keluarga, maka semakin besar proporsi anak berat badan kurang dan buruk. Berat badan kurang dan buruk lebih banyak terjadi di perdesaan.

Hasil analisis menunjukkan bahwa jenis bahan makanan yang paling banyak dikonsumsi oleh anak balita adalah serealia, akar, dan umbi-umbian, dimana hampir semua baduta mengonsumsi kelompok bahan makanan ini $(99,2 \%)$. Jenis kelompok bahan makanan yang paling sedikit dikonsumsi oleh anak balita yaitu buah-buahan (23\%) serta kacang-kacangan $(28,9 \%)$. Lebih dari separuh balita mengonsumsi sayuran (58\%), daging/ikan $(68,5 \%)$ dan susu dan olahan nya $(59 \%)$.

Distribusi keragaman konsumsi balita menurut karakteristik ditunjukkan dalam Tabel 3. Keragaman konsumsi balita berbeda bermakna berdasarkan umur ballita, umur ibu, pendidikan ibu, kondisi sosial ekonomi dan tempat tinggal. Semakin tinggi usia,semakin tinggi pendidikan ibu, semakin tinggi tingkat ekonomi maka semakin beragam konsumsi makanannya. Keragaman konsumsi juga lebih banyak pada balita di perkotaan.

Multivariat multinomial regresi status gizi dan independen utama keragaman konsumsi, dengan menyertakan covariat lain yaitu karakteristik anak, ibu dan rumah tangga (Tabel 4). Dilakukan uji interaksi dalam multivariat, yaitu interaksi keberagaman konsumsi dengan umur anak, pendidikan ibu, status ekonomi dan wilayah tempat tinggal, yang menunjukkan tidak terjadi interaksi. Dari multivariat multinomial regresi, diperoleh hasil peluang anak menjadi status gizi lebih daripada status gizi normal akan berkurang sebesar 0,149 jika anak tidak mengonsumsi makanan yang beragam. Atau jika anak tidak mengonsumsi makanan 
beragam, maka risiko relatif untuk menjadi gizi lebih daripada normal akan berkurang sebesar 0,86 . Peluang anak menjadi status berat badan kurang daripada status gizi normal akan bertambah sebesar 0,024 jika anak tidak mengonsumsi makanan yang beragam. Atau jika anak tidak konsumsi makanan beragam, maka risiko relatif untuk menjadi berat badan kurang daripada normal sebesar 1,03. Peluang anak menjadi status berat badan sangat kurang daripada status gizi normal akan bertambah sebesar 0,283 jika anak tidak Konsumsi makanan yang beragam. Atau jika anak tidak konsumsi makanan beragam, maka risiko relatif untuk menjadi berat badan kurang daripada normal akan meningkat sebesar 1,33.

Tabel 1

Karakteristik Balita

\begin{tabular}{|c|c|c|}
\hline \multirow{2}{*}{ Karakteristik } & \multicolumn{2}{|c|}{ Total sampel } \\
\hline & $n=5.395$ & $\%$ \\
\hline \multicolumn{3}{|l|}{ Karakteristik anak } \\
\hline \multicolumn{3}{|l|}{ Jenis Kelamin } \\
\hline Laki-laki & 2.647 & 49,1 \\
\hline Perempuan & 2.748 & 50,9 \\
\hline \multicolumn{3}{|l|}{ Umur Anak (bulan) } \\
\hline $24-59$ & 4.148 & 76,9 \\
\hline $12-23$ & 782 & 14,5 \\
\hline $9-11$ & 257 & 4,8 \\
\hline 6-8 & 208 & 3,9 \\
\hline \multicolumn{3}{|l|}{ Status gizi (BB/U) } \\
\hline Gizi lebih & 95 & 1,8 \\
\hline Normal & 4.288 & 79,5 \\
\hline Berat badan kurang & 854 & 15,8 \\
\hline Berat badan sangat kurang & 253 & 4,7 \\
\hline \multicolumn{3}{|l|}{ Keberagaman konsumsi } \\
\hline Beragam & 3.081 & 57,1 \\
\hline Tidak beragam & 2.314 & 42,9 \\
\hline \multicolumn{3}{|l|}{ Karakteristik lbu Balita } \\
\hline \multicolumn{3}{|l|}{ Umur Ibu (tahun) } \\
\hline $20-35$ & 3.605 & 66,8 \\
\hline$<20$ dan $>35$ & 1.790 & 33,2 \\
\hline \multicolumn{3}{|l|}{ Pendidikan Ibu } \\
\hline Pendidikan tinggi & 567 & 10,5 \\
\hline Pendidikan menengah & 2.772 & 51,4 \\
\hline Pendidikan rendah & 1.893 & 35,1 \\
\hline Tidak sekolah & 163 & 3,0 \\
\hline \multicolumn{3}{|l|}{ Pekerjaan Ibu } \\
\hline Tidak bekerja & 3.258 & 60,4 \\
\hline Bekerja/sekolah & 2.137 & 39,6 \\
\hline \multicolumn{3}{|l|}{ Karakteristik Rumah Tangga } \\
\hline \multicolumn{3}{|l|}{ Status ekonomi } \\
\hline Teratas & 1.273 & 23,6 \\
\hline Menengah atas & 1.225 & 22,7 \\
\hline Menengah & 1.018 & 18,9 \\
\hline Menengah bawah & 959 & 17,8 \\
\hline Terbawah & 920 & 17,1 \\
\hline \multicolumn{3}{|l|}{ Wilayah Tempat Tinggal } \\
\hline Perdesaan & 2.626 & 48,7 \\
\hline Perkotaaan & 2.769 & 51,3 \\
\hline
\end{tabular}


Tabel 2

Distribusi Status Gizi Balita menurut Karakteristik

\begin{tabular}{|c|c|c|c|c|c|c|}
\hline \multirow[t]{2}{*}{ Karakteristik } & $\begin{array}{c}\text { Total } \\
\text { sampel }\end{array}$ & $\begin{array}{l}\text { Gizi } \\
\text { lebih }\end{array}$ & Normal & $\begin{array}{l}\text { Berat } \\
\text { badan } \\
\text { kurang }\end{array}$ & $\begin{array}{l}\text { Berat } \\
\text { badan } \\
\text { sangat } \\
\text { kurang }\end{array}$ & \multirow[t]{2}{*}{$p$-value } \\
\hline & $\mathrm{n}$ & $\%$ & $\%$ & $\%$ & $\%$ & \\
\hline \multicolumn{7}{|l|}{ Karakteristik Anak } \\
\hline Jenis Kelamin & & & & & & 0,558 \\
\hline Perempuan & 2.748 & 1,7 & 78,5 & 15,2 & 4,6 & \\
\hline Laki-laki & 2.647 & 1,8 & 76,9 & 16,4 & 4,8 & \\
\hline Umur Anak (bulan) & & & & & & 0,000 \\
\hline $24-59$ & 4.148 & 1,2 & 77,1 & 16,9 & 4,9 & \\
\hline $12-23$ & 782 & 4,2 & 78,8 & 13,6 & 3,4 & \\
\hline $9-11$ & 257 & 2,7 & 80,5 & 11,3 & 5,4 & \\
\hline 6-8 & 208 & 2,9 & 83,6 & 9,1 & 4,3 & \\
\hline \multicolumn{7}{|l|}{ Karakteristik Ibu } \\
\hline Umur lbu (tahun) & & & & & & 0,019 \\
\hline $20-35$ & 3.605 & 2,1 & 77,2 & 15,6 & 5,1 & \\
\hline$<20$ dan $>35$ & 1.790 & 1,2 & 78,7 & 16,3 & 3,8 & \\
\hline Pendidikan Ibu & & & & & & 0,000 \\
\hline Pendidikan tinggi & 567 & 3,5 & 86,1 & 8,6 & 1,8 & \\
\hline Pendidikan menengah & 2.772 & 1,7 & 79,5 & 14,7 & 4,2 & \\
\hline Pendidikan rendah & 1.893 & 1,3 & 73,3 & 19,2 & 6,2 & \\
\hline Tidak sekolah & 163 & 1,8 & 70,6 & 20,9 & 6,8 & \\
\hline Pekerjaan Ibu & & & & & & 0,192 \\
\hline Tidak bekerja & 3.258 & 1,7 & 76,8 & 16,6 & 4,9 & \\
\hline Bekerja/sekolah & 2.137 & 1,8 & 79,1 & 14,7 & 4,4 & \\
\hline \multicolumn{7}{|l|}{ Karakteristik Rumah Tangga } \\
\hline Status ekonomi & & & & & & 0,000 \\
\hline Teratas & 1.273 & 2,0 & 83,3 & 12,2 & 2,4 & \\
\hline Menengah atas & 1.225 & 2,0 & 79,6 & 14,6 & 3,8 & \\
\hline Menengah & 1.018 & 1,5 & 76,3 & 17,0 & 5,2 & \\
\hline Menengah bawah & 959 & 1,4 & 75,3 & 17,3 & 6,1 & \\
\hline Terbawah & 920 & 1,7 & 71,6 & 19,6 & 7,1 & \\
\hline Wilayah Tempat Tinggal & & & & & & 0,002 \\
\hline Perkotaaan & 2.626 & 1,7 & 79,7 & 14,8 & 3,8 & \\
\hline Perdesaan & 2.769 & 1,8 & 75,8 & 16,8 & 5,5 & \\
\hline
\end{tabular}


Tabel 3

Distribusi Keragaman Konsumsi Balita menurut Karakteristik

\begin{tabular}{|c|c|c|c|c|}
\hline Karakteristik & $\begin{array}{c}\text { Total } \\
\text { sampel } \\
n\end{array}$ & $\begin{array}{c}\text { Beragam } \\
\%\end{array}$ & $\begin{array}{c}\text { Tidak beragam } \\
\%\end{array}$ & $p$-value \\
\hline \multicolumn{5}{|l|}{ Karakteristik Anak } \\
\hline Jenis Kelamin & & & & 0,147 \\
\hline Perempuan & 2.748 & 58,1 & 41,9 & \\
\hline Laki-laki & 2.647 & 56,2 & 43,9 & \\
\hline Umur Anak (bulan) & & & & 0,000 \\
\hline $24-59$ & 4.148 & 61,33 & 38,7 & \\
\hline $12-23$ & 782 & 54,6 & 45,4 & \\
\hline $9-11$ & 257 & 29,6 & 70,4 & \\
\hline $6-8$ & 208 & 16,4 & 83,7 & \\
\hline \multicolumn{5}{|l|}{ Karakteristik Ibu } \\
\hline Umur lbu (tahun) & & & & 0,225 \\
\hline $20-35$ & 3.605 & 56,5 & 43,5 & \\
\hline$<20$ dan $>35$ & 1.790 & 58,3 & 41,7 & \\
\hline Pendidikan Ibu & & & & 0,000 \\
\hline Pendidikan tinggi & 567 & 75,3 & 24,7 & \\
\hline Pendidikan menengah & 2.772 & 60,1 & 39,9 & \\
\hline Pendidikan rendah & 1.893 & 48,8 & 51,2 & \\
\hline Tidak sekolah & 163 & 39,9 & 60,1 & \\
\hline Pekerjaan lbu & & & & 0,098 \\
\hline Tidak bekerja & 3.258 & 58,0 & 41,9 & \\
\hline Bekerja/sekolah & 2.137 & 55,7 & 44,3 & \\
\hline \multicolumn{5}{|l|}{ Karakteristik Rumah Tangga } \\
\hline Status ekonomi & & & & 0,000 \\
\hline Teratas & 1.273 & 67,9 & 32,1 & \\
\hline Menengah atas & 1.225 & 63,3 & 36,7 & \\
\hline Menengah & 1.018 & 59,5 & 40,5 & \\
\hline Menengah bawah & 959 & 53,6 & 46,4 & \\
\hline Terbawah & 920 & 35,0 & 65,0 & \\
\hline Wilayah Tempat Tinggal & & & & 0,000 \\
\hline Perkotaaan & 2.626 & 65,1 & 34,9 & \\
\hline Perdesaan & 2.769 & 49,5 & 50,5 & \\
\hline
\end{tabular}

Tabel 4

Multinomial Regresi

\begin{tabular}{lccc}
\hline Variabel & Berat badan lebih & Berat badan kurang & $\begin{array}{c}\text { Berat badan } \\
\text { sangat } \\
\text { kurang }\end{array}$ \\
\hline Konsumsi tidak beragam & $-0,141(0,746)$ & $0.028(0.832)$ & $0.288(0.265)$ \\
Coefisien $(p$-value $)$ & $0,86(0,746)$ & $1.03(0.832)$ & $1.33(0.265)$ \\
RR $(p$-value $)$ & Keterangan: di-ajust dengan variabel karakteristik anak, karakteristik ibu, dan rumah tangga &
\end{tabular}




\section{BAHASAN}

Hasil analisis menunjukkan bahwa jenis bahan makanan yang paling banyak dikonsumsi oleh anak balita di Indonesia adalah serealia, akar, dan umbi-umbian, dimana hampir semua baduta mengonsumsi kelompok bahan makanan ini. Hasil analisis juga menunjukkan bahwa jenis kelompok bahan makanan yang paling sedikit dikonsumsi oleh anak balita yaitu buah-buahan serta kacang-kacangan. Hal ini sejalan dengan sebuah analisis yang dilakukan pada 7 negara di Asia tenggara termasuk didalamnya yaitu Birma, Kamboja, Indonesia, Laos, Filipina, Timor Leste, dan Vietnam menunjukkan bahwa kualitas dan kuantitas konsumsi makanan balita di Asia masih menjadi perhatian penting. Dimana di beberapa negara Asia, konsumsi makanan masih rendah kandungan gizi mikro nya (terutama daging dan protein hewani serta sayur dan buah-buahan tertentu), tinggi konsumsi makanan yang dapat menghambat penyerapan zat gizi penting seperti besi dan seng. Diet monoton yang didominasi oleh serealia seperti nasi juga dianggap menjadi faktor penyumbang terjadi nya defisiensi zat gizi mikro di Asia. ${ }^{9}$ Pola konsumsi dominasi sereal dan umbi-umbian sama dengan pola pada balita di Afrika (Ethiopia, Nigeria), dengan hanya sepersepuluh balita yang mengonsumsi kelompok susu dan produknya, daging, telur, ikan. Termasuk hanya sedikit yang mengonsumsi buah-buahan, terutama yang mengandung vitamin A (pepaya dan mangga). $10,11,12$

Keragaman konsumsi bahan makanan adalah proksi kualitas pola makan dan kecukupan gizi. ${ }^{13,14}$. Ketidakberagaman bahan makanan yang dikonsumsi merupakan masalah bagi negara berkembang, dimana rendah konsumsi produk hewani, dan sedikit buah dan sayur. Ditambah bahan makanan pokok nabati yang dikonsumsi miskin kandungan mikronutrien, dan mikronutrien yang dikandungpun termasuk dalam jenis yang sulit diserap oleh tubuh. ${ }^{15}$ WHO merekomendasikan pemberian makanan pelengkap bagi anak-anak mulai usia 6 bulan untuk memenuhi kebutuhan kalori, protein dan mikronutrien yang dibutuhkan untuk tumbuh kembangnya. ${ }^{12}$ Pemberian makanan yang tepat selama masa anak-anak penting juga untuk pencegahan penyakit kronis degeneratif di masa mendatang. ${ }^{16}$ Pemberian makanan yang tidak tepat (dalam hal kandungan gizi) akan meningkatkan risiko gizi buruk, gangguan penyakit dan kematian anakanak. ${ }^{17}$ Diperkirakan 6 persen kematian balita dapat dicegah dengan pemberian keanekaragaman makanan yang optimal. ${ }^{18}$

Sebuah studi keragaman makanan rumah tangga yang memiliki balita yang pernah dilakukan di Provinsi Jawa Tengah menyatakan bahwa beras merupakan makanan pokok yang dikonsumsi oleh masyarakat, dimana beras menyumbangkan sekitar 70 persen dari total energi harian. Berbeda dengan hasil analisis keragaman makanan balita di Indonesia ini, studi di Jawa Tengah menemukan bahwa kacang-kacangan dan sayuran banyak dikonsumsi oleh rumah tangga. Hal ini menunjukkan bahwa pengaruh etnis memberi perbedaan pada pola makan dari masyarakatnya. Dimana dalam hal ini mayoritas masyarakat di Jawa Tengah beretnis Jawa. ${ }^{19}$ Sebuah studi lain di Afrika selatan menemukan bahwa makanan yang dominan dikonsumsi anak usia 6-23 bulan di daerah tersebut yaitu gandumg dan polong-polongan. Sedangkan konsumsi makanan hewani seperti daging dan telur rendah. ${ }^{20}$ Studi di Thailand menunjukkan konsumsi kacang-kacangan mencapai hampir 30 persen, sayuran 25 persen, buah-buahan hampir 60 persen dengan bahan beras dan umbi-umbian yang juga dikonsumsi hampir seluruh anak. Bahkan di Madagaskar hampir 50 persen anak-anak mengonsumsi kacang-kacangan, polongpolongan dan buah-buahan, meski konsumsi daging dan produk susu masih rendah. ${ }^{21}$ Hasil analisis juga menunjukkan bahwa semakin tinggi usia, semakin tinggi pendidikan ibu serta semakin tinggi tingkat ekonomi maka semakin beragam konsumsi makanannya. Keragaman konsumsi juga lebih banyak pada balita di perkotaan. Hasil ini sejalan dengan studi di Filipina dan Thailand yang menemukan bahwa lebih banyak anak dengan usia lebih tua yang memiliki nilai keragaman makanan minimal dibandingkan dengan anak yang usia nya lebih muda. Anak dari keluarga dengan ketahanan makanan yang lebih baik serta tinggal di perkotaan juga memiliki keragaman makanan yang lebih baik daripada anak yang berasal dari keluarga dengan ketahanan pangan yang rendah.7,22 Studi yang dilakukan di Ghana menemukan hasil yang sejalan, dimana 
terdapat tren keragaman makanan semakin tinggi sejalan dengan usia anak. Hal ini merupakan tren yang baik untuk gizi anak, karena orangtua atau pengasuh telah memahami kebutuhan gizi anak mengikuti proses pertumbuhannya. Keragaman makanan juga secara siknifikan lebih tinggi pada ibu dengan pendidikan yang tinggi. Hal ini sesuai dengan opini sebelumnya bahwa dengan tingkat pendidikan yang cukup, ibu akan mengerti mengenai pentingnya gizi seimbang bagi anak. Hal ini bisa menjadi salah satu landasan penting nya kesadaran gizi agar dapat masuk ke dalam kurikulum sekolah, terutama pada tingkat pendidikan dasar. ${ }^{23}$

Hasil analisis mengindikasikan bahwa jika anak tidak mengonsumsi makanan beragam, maka risiko relatif untuk memiliki berat badan kurang daripada normal meningkat sebesar 1,03. Bahkan, jika anak tidak mengonsumsi makanan beragam, maka risiko relatif untuk menjadi berat badan sangat kurang daripada normal akan meningkat sebesar 1,33. Hal ini sejalan dengan studi di Filipina yang juga menemukan hubungan antara keragaman makanan dengan berat badan kurang (BB/U) dan kekurusan (BB/TB) pada anak. Memenuhi keragaman makanan minimal merupakan faktor protektif terhadap berat badan kurang (Odds Ratio $(\mathrm{OR})=0.80,95 \%$ Confidence Interval $(\mathrm{Cl})$ 0.64-1.00) dan kekurusan $(\mathrm{OR}=0.62,95 \% \mathrm{Cl}$ 0.46-0.82). ${ }^{7} \quad$ Analisis dari data di Asia Timur menunjukkan bahwa selain ketahanan pangan rumah tangga, keragaman makanan juga secara siknifikan berhubungan dengan kekurusan serta anemia. ${ }^{24}$ Studi di Cina juga menunjukkan hasil yang sama dimana indeks makan anak yang didalamnya terdapat keragaman makanan memiliki hubungan dengan kekurusan dan berat badan kurang pada anak. ${ }^{25}$ Sebuah studi di Etiopia juga menemukan bahwa ketidak beragaman makanan menunjukkan efek yang negatif terhadap pertumbuhan dan perkembangan anak. ${ }^{8}$ Studi di Ghana menunjukkan hasil yang sejalan, dimana keragaman makanan berdampak pada kesehatan anak balita di Ghana. Akan tetapi, peneliti berusaha untuk menginterpretasikan hasil analisis nya dengan hati-hati karena keragaman makanan hanya dihitung berdasarkan food-recall 1×24 jam, sehingga tidak dianggap akurat untuk merefleksikan pola makan untuk periode yang lama. Namun, terlepas dari kelemahan ini, analisis yang dilakukan menunjukkan hubungan yang konsisten dengan 3 indikator pertumbuhan. ${ }^{23}$

Keragaman makanan juga ditemukan berhubungan dengan pendek pada anak di beberapa studi. Studi di Banglades menemukan bahwa keragaman makanan berhubungan dengan pendek pada anak di seluruh kelompok umur. Pada analisis multivariat, dibandingkan dengan keragaman makanan yang rendah, keragaman makanan yang tinggi berhubungan dengan pengurangan odds menjadi pendek sebanyak 15,26 dan 31 persen pada anak usia 6-11, 12-23, 24-59 bulan, setelah dikontrol oleh faktor perancu. ${ }^{26}$ Begitu pula analisis dari data di Asia Timur menunjukkan bahwa selain ketahanan pangan rumah tangga, keragaman makanan juga secara siknifikan berhubungan dengan pendek pada anak. ${ }^{24}$ Berbeda dengan hasil-hasil tersebut, studi di Cina tidak menemukan hubungan dengan pendek pada anak. ${ }^{25}$

Hasil analisis juga menunjukkan bahwa jika anak tidak mengonsumsi makanan beragam, maka risiko relatif untuk memiliki berat badan lebih daripada normal akan berkurang sebesar 0,86 , atau dengan kata lain mengonsumsi makanan yang beragam merupakan faktor resiko terjadi nya berat badan yang berlebih. Hal ini sesuai dengan hasil beberapa studi sebelumnya. Di Iran studi yang dilakukan terhadap anak usia sekolah (6-9 tahun) menunjukkan bahwa anak-anak dengan berat badan lebih atau gemuk memiliki skor keragaman makanan yang lebih tinggi. ${ }^{27}$ Studi pada orang dewasa di Srilangka juga mendapatkan hasil yang sama, dimana skor keragaman makanan lebih tinggi pada orang yang gemuk. ${ }^{28}$

Sebuah studi di Mali menjelaskan bahwa terdapat hubungan positif antara energi intake dengan skor keragaman makanan. ${ }^{29}$ Studi pada hewan dan manusia menunjukkan bahwa bertambahnya jenis bahan makanan yang dikonsumsi akan meningkatkan berat badan dan selanjutnya ke arah obesitas. ${ }^{30}$.

Akan tetapi terdapat beberapa hasil studi dengan hasil yang berbeda. Dimana studi pada pelajar wanita di Universitas Isfahan menemukan hubungan invers antara skor keragaman makanan dengan obesitas. Begitu pula pada wanita di United States (US) , dimana 
nilai IMT yang rendah berhubungan skor keragaman makanan yang rendah. ${ }^{17}$ Perbedaan ini mungkin disebabkan karena perbedaan metode yang digunakan dalam menghitung keragaman makanan. Beberapa studi ada yang menggunakan metode recall 24 jam, dan ada juga yang menggunakan food frequency questionairre (ffq). Beberapa studi, demikian hal nya juga dalam SKMI ini, keragaman makanan dihitung berdasarkan banyaknya kelompok bahan makanan serta frekuensi konsumsi nya. Akan tetapi porsi tidak dipertimbangkan. Hal ini mungkin dapat menyebabkan pada anak-anak yang gemuk, cenderung mengonsumsi lebih banyak sayuran seperti kentang yang berkontribusi pada nilai kalori yang dikonsumsi. Selain itu jenis penyajian juga sangat berpengaruh, dimana penyajian-penyajian tertentu mungkin banyak mengandung lemak dan minyak. ${ }^{28}$

Keragaman makanan yang rendah merupakan permasalahan yang serius pada masyarakat miskin di negara-negara berkembang, dimana makanan mereka didominasi oleh makanan pokok yang bertepung dan biasanya rendah atau tidak mengandung makanan hewani dan sedikit buah dan sayuran. Diet berbasis tumbuhan ini cenderung rendah kandungan gizi mikro nya dan gizi mikro yang dikandung juga biasanya ada dalam bentuk yang sulit untuk diabsorbsi. Walaupun aspek lain dari kualitas makanan, seperti konsumsi lemak, garam dan gula, belum menjadi perhatian di negara-negara berkembang, akan tetapi perubahan global konsumsi makanan dan pola aktifitas yang disebabkan oleh peningkatan pendapatan dan urbanisasi juga menyebabkan permasalahan ini relefan di negara-negara yang mengalami transisi ini juga. ${ }^{20,31}$

Hasil penelitian menunjukkan konsumsi buah dan kacang-kacangan masih rendah pada balita, begitu juga konsumsi telur. Beberapa jenis makanan ini mengandung vitamin $A$ yang sangat berhubungan positif terhadap indikator TB/U. ${ }^{12}$ Penelitian juga menunjukkan hubungan signifikan pendidikan ibu dengan keragaman konsumsi. Peluang besar yang dapat dimanfaatkan oleh pemerintah adalah menyampaikan materi literasi tentang manfaat keberagaman konsumsi bahan pangan bagi pertumbuhan anak melalui bermacam sarana literasi baik formal ataupun non-formal. Literasi yang baik akan menumbuhkan kesadaran dan praktek pengasuhan yang lebih baik. Sehingga diharapkan praktek pemberian makanan beranekaragam akan terwujud guna mencukupi kebutuhan makronutrien dan mikronutrien pendukung tumbuh kembang anak.

Penelitian ini memiliki keterbatasan yaitu dalam hal metodologi, dimana disain potong lintang memiliki kelemahan dalam menjelaskan hubungan variabel independen dan dependen. Metode recall konsumsi yang digunakan adalah recall dalam 24 jam sebelumnya belum dapat menggambarkan "usual intake" anak. Selain itu karena analisis ini dilakukan pada dua studi nasional yang tidak dilakukan bersamaan yaitu Riskesdas pada 2013 serta SKMI pada 2014 terdapat beberapa variabel yang tidak relevan untuk dianalisis padahal variabel tersebut merupakan variabel penting yang mungkin dapat mempengaruhi kondisi status gizi anak seperti pemberian ASI, morbiditas serta kondisi kesehatan lingkungan.

\section{SIMPULAN DAN SARAN}

\section{Simpulan}

Hasil analisis menunjukkan bahwa jenis bahan makanan yang paling banyak dikonsumsi oleh anak balita di Indonesia adalah serealia, akar, dan umbi-umbian sementara jenis kelompok bahan makanan yang paling sedikit dikonsumsi oleh anak balita yaitu buah-buahan serta kacang-kacangan. Hasil analisis juga menunjukkan bahwa semakin tinggi usia, semakin tinggi pendidikan ibu serta semakin tinggi tingkat ekonomi maka semakin beragam konsumsi makanannya. Keragaman konsumsi juga lebih banyak pada balita di perkotaan.

Penelitian ini menunjukkan bahwa keragaman bahan pangan yang dikonsumsi balita berhubungan dengan kondisi status gizi. Konsumsi yang kurang beragam terutama meningkatkan risiko seorang balita mengalami berat badan sangat kurang, meskipun hubungan ini lemah. Sebaliknya, konsumsi yang kurang beragam menurunkan resiko terjadinya berat badan lebih.

\section{Saran}

Masih banyaknya balita dengan konsumsi yang rendah keragaman makanan nya ini menuntut konsekuensi perhatian yang lebih banyak pada orangtua untuk lebih 
memperhatikan keragaman bahan makanan yang dikonsumsi. Perlunya pendidikan bagi orangtua melalui berbagai media tentang manfaat keanekaragaman bahan makanan bagi balita sehingga tidak akan terancam pada kondisi berat badan sangat kurang. Perlunya penelitian lebih lanjut tentang komposisi masing-masing jenis bahan makanan yang lebih detail agar lebih teknis dalam praktek pemberian makanan pada balita.

\section{UCAPAN TERIMA KASIH}

Ucapan terima kasih kami sampaikan kepada Kepala Badan Penelitian dan Pengembangan Kesehatan, ketua pelaksana studi Survei Konsumsi Makanan Individu (SKMI) serta seluruh tim peneliti.

\section{RUJUKAN}

1. Kementerian Kesehatan Republik Indonesia. Pedoman Gizi Seimbang. Peraturan Menteri Kesehatan Republik Indonesia Nomor 41. 2014. 1-96 p.

2. Amugsi DA, Mittelmark MB, Oduro A. Association between maternal and child dietary diversity: An analysis of the Ghana Demographic and Health Survey. PLoS One. 2015;10(8):1-12.

3. Badan Penelitian dan Pengembangan Kesehatan. Laporan Riset Kesehatan Dasar. Jakarta: Lembaga Penerbit Badan Penelitian dan Pengembangan Kesehatan; 2013.

4. Badan Penelitian dan Pengembangan Kesehatan. Riset Kesehatan Nasional Studi Diet Total 2014. Jakarta; 2014.

5. de Onis $M$, Onyango $A$, Borghi $E$, Siyam A, Pinol A. . WHO Child Growth Standards. World Health Organization. Geneva, Switzerland; 2006.

6. WHO. Indicators for Assessing Infant and Young Child Feeding Practices. World Heal Organ [Internet]. 2010;119. Available from: http://scholar.google.com/scholar?hl=e $n \& b t n G=S e a r c h \& q=i n t i t l e: I n d i c a t o r s+f o$ $r+$ assessing+infant+and+young+child+ feeding+practices\#0

7. Ocampo-Guirindola ML, GarciaMalabad CJ, Valdeabella-Maniego MLM, Punzalan SLM. Association between dietary diversity score and nutritional status of Filipino children aged 6-23 months. Philipp J Sci. 2016;145(1):57-69.

8. Aemro $M$, Mesele $M$, Birhanu $Z$, Atenafu A, Aemro M, Mesele M, et al. Dietary Diversity and Meal Frequency Practices among Infant and Young Children Aged 6-23 Months in Ethiopia: A Secondary Analysis of Ethiopian Demographic and Health Survey 2011. Nutr Metab. 2013;2013, 2013:e782931. Available from: http://www.hindawi.com/journals/jnme/ 2013/782931/abs/, http://www.hindawi.com/journals/jnme/ 2013/782931/abs/\%5Cnhttp://downloa ds.hindawi.com/journals/jnme/2013/78 2931.pdf\%5Cnhttp://www.hindawi.com/ journals/jnme/2013/782931/\%5Cnhttp:/ /www.ncbi.nlm.nih.gov/

9. Chaparro C, Oot L, Sethuraman K. Overview of the Nutrition Situation in Seven Countries in Southeast Asia [Internet]. Fanta 111, Usaid. 2014. Available from: https://www.fantaproject.org/sites/defa ult/files/download/Southeast-AsiaNutrition-Overview-Apr2014.pdf

10. Hailemariam T, Girmany T, Girmany G. Determinants Of Individual Dietary Diversity Score Of Children Less Than Five Years Old In The Southern Zone Of Tigray, Ethiopia. Afr. J. Food Agric. Nutr. Dev. 2018; 18(1): 13034-13051 Doi: 10.18697/Ajfand.81.16400

11. Ogechi UP, Chilezie OV. Assessment of Dietary Diversity Score, Nutritional Status and Socio-demographic Characteristics of Under-5 Children in Some Rural Areas of Imo State, Nigeria. Mal J Nutr. 2017, 23(3): 425 435

12. Agize A, Jara D, Dejenu G. Level of Knowledge and Practice of Mothers on Minimum Dietary Diversity Practices and Associated Factors for 6-23Month-Old Children in Adea Woreda, Oromia, Ethiopia. BioMed Research International. 2017,https://doi.org/10.1155/2017/720 4562

13. Moursi MM, Arimond M, Dewey KG., 
Treche S, Ruel MT, Delpeuch F. Community and International Nutrition. 2008, p. 2448-2453. doi:10.3945/jn.108.093971

14. Kennedy G, Ballard T, Dop M. Guidelines for Measuring Household and Individual Dietary Diversity. 2013.

15. World Health Organization ( WHO). Preparation and use of foodbased dietary guidelines. 1996. Switzerland: Geneva.

16. Black RE, Allen LH, Bhutta ZA, Caulfield LE, de Onis M, Ezzatti M et al. Maternal and child undernutrition: global and regional exposures and health consequences. The Lancet. 2008, vol. 371 , no. 9608 , pp. 243-260

17. Lutter $C$. Meeting the challenge to improve complementary feeding and strengthening action to feeding. SCN News. 2003, vol. 27, pp. 4-9

18. Black RE, Morris SS, and Bryce J. Where and why are 10 million children dying every year?. Lancet. 2003; 361 (9376): 2226-2234.

19. Mahmudiono $T$, Sumarmi $S$, Rosenkranz RR. Household dietary diversity and child stunting in East Java, Indonesia. Asia Pac J Clin Nutr. 2017;26(2):317-25.

20. Gatahun EA, Abyu DM. Dietary diversity feeding practice and determinants among children aged 623 months in Kemba Woreda, southern Ethiopia implication for public health intervention. J Nutr Food Sci [Internet]. 2015;5(Special issue 13):S13-003. Available from: http://www.omicsonline.org/openaccess/dietary-diversity-feedingpractice-and-determinants-amongchildren-aged-623-months-in-kembaworeda-southern-ethiopia-implicationfor-public-health-intervention-21559600-S13-003.php?aid=57399

21. Rakotonirainy $\mathrm{NH}$, Razafindratovo VA, Remonja CR, Rasoloarijona R, Piola P, Raharintsoa C, Randremanana RV. Dietary diversity of 6 - to 59-month-old children in rural areas of Moramanga and Morondava districts, Madagascar. PLOS ONE. 2018; 13(7): 2-14. https://doi.org/

\subsection{1/journal.pone. 0200235}

22. Roesler Anna L, Smithers LG, Wangpakapattanawong $\mathrm{P}$, Moore $\mathrm{V}$. Stunting, dietary diversity and household food insecurity among children under 5 years in ethnic communities of northern Thailand. Journal of Public Health. 2018; 41(4): 772-780. doi:10.1093/pubmed/fdy201

23. Frempong RB, Annim SK. Dietary diversity and child malnutrition in Ghana. Heliyon [Internet]. 2017;3(5):e00298. Available from: http://dx.doi.org/10.1016/j.heliyon.2017 .$e 00298$

24. McDonald CM, McLean $\mathrm{J}$, Kroeun $\mathrm{H}$, Talukder A, Lynd LD, Green TJ. Household food insecurity and dietary diversity as correlates of maternal and child undernutrition in rural Cambodia. Eur $\mathrm{J}$ Clin Nutr [Internet]. 2015;69(2):242-6. Available from: http://dx.doi.org/10.1038/ejcn.2014.161

25. Zhang J, Shi L, Wang J, Wang Y. An infant and child feeding index is associated with child nutritional status in rural China. Early Hum Dev [Internet]. 2009;85(4):247-52. Available from: http://dx.doi.org/10.1016/j.earlhumdev. 2008.10.009

26. Rah JH, Akhter N, Semba RD, Pee S de, Bloem MW, Campbell AA, et al. Low dietary diversity is a predictor of child stunting in rural Bangladesh. Eur $\mathrm{J}$ Clin Nutr [Internet]. 2010;64(12):1393-8. Available from: http://www.nature.com/doifinder/10.103 8/ejcn.2010.171

27. Hooshmand S, Marhamati F. High dietary diversity is associated with child obesity in Iranian school children: An evaluation of dietary diversity score . J Nutr Hum Heal. 2018;2(1):2-7.

28. Jayawardena R, Byrne NM, Soares MJ, Katulanda P. High dietary diversity is associated with obesity in Sri Lankan adults : an evaluation of three dietary scores. BMC Public Health. 2013;13(April).

29. Torheim LE, Ouattara F, Diarra MM, Thiam FD, Barikmo I, Hatl A, et al. Nutrient adequacy and dietary diversity 
in rural Mali : association and determinants. Eur J Clin Nutr. 2004;58:594-604.

30. Raynor HA, Epstein LH. Dietary Variety, Energy Regulation, and
Obesity. Psychol Bull. 2001;127(3):325-41.

31. Popkin BM. The Nutrition Transition in Low-Income Countries: An Emerging Crisis. Nutr Rev. 1994;52(9):285-98. 